\title{
Cancer patient survival by socioeconomic status in The Netherlands: a review for six common cancer sites
}

\author{
Carola T M Schrijvers, Johan P Mackenbach
}

\begin{abstract}
Study objective - To study the size and consistency of socioeconomic differences in cancer patient survival as reported in published studies.

Methods - A systematic review was conducted. Several criteria were developed to select the study material, which resulted in 14 reports on socioeconomic differences in survival for cancers of the colon, rectum, lung, prostate, breast, and cervix. These present results on patients from the United States, Japan, Australia, United Kingdom, Sweden, Finland, and Germany. The results are summarised in a relative risk of dying or survival ratio for the lowest socioeconomic status group compared with the highest.

Results - For cancers of the colon, rectum, breast, and cervix, patients from higher socioeconomic status groups had a better survival. For lung cancer and cancer of the prostate, results were unclear.

Conclusion - Socioeconomic differences in cancer survival are generally small and their contribution to socioeconomic differences in cancer mortality is probably small too. These findings have implications for the type of health policy measures which should be taken to reduce socioeconomic differences in cancer mortality.
\end{abstract}

\section{(f Epidemiol Community Health 1994;48:441-446)}

Socioeconomic differences in mortality have been reported for a variety of causes of death including cancer. ${ }^{12}$ Cancer mortality is generally higher in people of low socioeconomic status compared with people of a high socioeconomic status. This mortality disadvantage may be the result of differences in cancer incidence or cancer survival.

Socioeconomic differences in cancer incidence and cancer survival do not call for the same health policy measures. Differences in cancer incidence ask for interventions in the area of primary prevention, whereas socioeconomic differences in cancer survival ask for policy measures in the area of secondary prevention or treatment.

We have tried to establish the size and consistency of socioeconomic differences in cancer survival, on the basis of a systematic review of the available published studies on the subject. This review deals with socioeconomic differences in cancer patient survival for a number of common cancer sites: colon, rectum, lung prostate, breast, and cervix.

\section{Methods}

The study material was selected through Medline and the references of papers and books, which resulted in 40 papers on socioeconomic differences in cancer survival. To enable a useful comparison of the results of the reviewed studies to be made some exclusion criteria were developed.

Studies on patients diagnosed in the 1950s or earlier were excluded.

Hospital based studies were excluded because cancer patients treated in specific hospitals may not be representative of cancer patients in the general population. In particular, socioeconomic contrast may be larger in the general population than in a hospital population.

Studies covering fewer than five years of follow up were excluded, because for many cancers survival differences may not yet be apparent shortly after diagnosis.

Three measures of socioeconomic status were considered to be unfit for our purpose. Studies using race as a measure were excluded, because it is difficult to separate the impact of socioeconomic status and other race related factors on survival. Studies that used hospital type or insurance status as a measure were also excluded, as we consider both variables to be intermediary in the socioeconomic status-survival association.

Studies that reported on fewer than 200 cancer deaths were excluded from this review. This number of events is the minimum needed to indicate a relative risk (RR) of dying of 1.5 when two socioeconomic groups with equal numbers are compared (with $\alpha=0.05$ and $\beta=$ $0 \cdot 20) .^{3}$

Cancer sites for which fewer than three papers on socioeconomic status and survival were available were not considered in this review.

Finally, 14 studies remained for inclusion in the review. Table 1 presents the most important characteristics of the selected papers, which are ordered by country of origin of the study population. ${ }^{4-19}$

The country of origin of the study population may be a determinant of the strength of socioeconomic differences in cancer survival. In general, these differences are expected to be smaller in countries like Sweden, with good access to health care facilities for the entire population.

The measures of socioeconomic status are 
divided into two broad categories: measures on the individual level such as education, ${ }^{8}$ occupation, ${ }^{14-18}$ or housing tenure ${ }^{13}$ and ecological measures in which the place of residence of cancer patients is used to assign a socioeconomic score. These measures are either based on census tract, ${ }^{4}$ block group,${ }^{5}$ postcode, ${ }^{671115}$ electoral ward, ${ }^{12}$ or community of residence. ${ }^{19}$

Table 1 shows that most studies cover the 1970 s and early 80 s with the exception of three which cover an incidence period starting in the $60 \mathrm{~s} .{ }^{4816}$

From table 1 it can be seen that different measures of survival were used. If the survival of cancer patients is studied, deaths due to causes other than the cancer(s) of interest must be excluded. In a number of studies the exact cause of death was known, and therefore patients dying from other causes than the spe- cific cancer could be treated as censored in the survival analysis. The resulting measure is called the corrected survival rate. ${ }^{4111^{17-19}}$ The relative survival rate, which is the ratio of the observed and expected survival rate, ${ }^{1617}$ is usually calculated when reliable information on the exact cause of death is not available. The expected survival rate is based on life tables of the general population.

A few studies did not report on the exclusion of deaths from other causes. ${ }^{51214}$ In two other studies the distributions of deaths related and not related to cancer were similar in the different socioeconomic categories and the authors did not therefore correct for deaths from other causes. ${ }^{67}$ Finally, the standardised case fatality ratio was employed in one study ${ }^{13}$ - the case fatality rates of the entire study population for the cancer in question were used as a standard.

For most studies an RR of dying for the

Table 1 Study population, measure of socioeconomic status (SES) and measure of survival for 14 published reports on socioeconomic differences in cancer survival

\begin{tabular}{|c|c|c|c|c|c|c|}
\hline $\begin{array}{l}\text { Ref } \\
\text { no }\end{array}$ & Population & $\begin{array}{l}\text { Cancer site } \\
(\text { sex })\end{array}$ & $\begin{array}{l}\text { No of } \\
\text { patients }\end{array}$ & SES measure & $\begin{array}{l}\text { Year of } \\
\text { diagnosis }\end{array}$ & $\begin{array}{l}\text { Measure of } \\
\text { survival }\end{array}$ \\
\hline 4 & Hawaii, USA & $\begin{array}{l}\text { Colon } \\
\text { Rectum }\end{array}$ & $\begin{array}{r}1446 \\
881\end{array}$ & $\begin{array}{l}\text { Ecological: weighted score based } \\
\text { on: average years of education and } \\
\text { average income per census tract; } \\
3 \text { categories }\end{array}$ & $1960-74$ & $\begin{array}{l}\text { Corrected } \\
\text { survival rate }\end{array}$ \\
\hline 5 & $\begin{array}{l}\text { Northwestern } \\
\text { Washington State, } \\
\text { USA }\end{array}$ & Breast & 1506 & $\begin{array}{l}\text { Ecological: social class, several } \\
\text { indicators (eg \% working class) } \\
\text { per block group of residence; } \\
2 \text { categories }\end{array}$ & $1973-83$ & Survival rate* \\
\hline 6 & USA & Prostate & 2513 & $\begin{array}{l}\text { Ecological: education, } \% \text { of high } \\
\text { school graduates, persons } \geq 25 \\
\text { years, per postcode of residence; } \\
4 \text { categories }\end{array}$ & $1977-81$ & Survival ratef \\
\hline 7 & USA & $\begin{array}{l}\text { Rectum } \\
\text { Colon }\end{array}$ & $\begin{array}{l}1528 \\
3617\end{array}$ & $\begin{array}{l}\text { Ecological: education, } \% \text { of high } \\
\text { school graduates, persons } \geq 25 \\
\text { years, per postcode of residence; } \\
3 \text { categories }\end{array}$ & $1977-82$ & Survival rate \\
\hline $\begin{array}{l}8,9 \\
10\end{array}$ & $\begin{array}{l}\text { Boston, USA } \\
\text { Tokyo, Japan }\end{array}$ & $\begin{array}{l}\text { Breast } \\
\text { Breast }\end{array}$ & $\begin{array}{l}563 \\
814\end{array}$ & $\begin{array}{l}\text { Individual: } \\
\text { education, in years of } \\
\text { schooling; } 2 \text { categories }\end{array}$ & $\begin{array}{l}1965-66 \\
1965-67\end{array}$ & $\begin{array}{l}\text { Survival } \\
\text { rate* }\end{array}$ \\
\hline 11 & $\begin{array}{l}\text { South } \\
\text { Australia }\end{array}$ & $\begin{array}{l}\text { Lung } \\
\text { Colon } \\
\text { Breast }\end{array}$ & $\begin{array}{l}2934 \\
2227 \\
2676\end{array}$ & $\begin{array}{l}\text { Ecological: } \\
\text { income, median male } \\
\text { income per postcode of } \\
\text { residence; } 3 \text { categories }\end{array}$ & $1977-82$ & $\begin{array}{l}\text { Corrected } \\
\text { survival } \\
\text { rate }\end{array}$ \\
\hline 12 & $\begin{array}{l}\text { Sheffield, } \\
\text { UK }\end{array}$ & Cervix & 548 & $\begin{array}{l}\text { Ecological: } \\
\text { occupation, \% of } \\
\text { semiskilled/unskilled } \\
\text { workers per electoral ward; } \\
5 \text { categories }\end{array}$ & $1971-84$ & $\begin{array}{l}\text { Survival } \\
\text { rate* }^{*}\end{array}$ \\
\hline 13 & $\begin{array}{l}\text { England \& } \\
\text { Wales }\end{array}$ & $\begin{array}{l}\text { Breast } \\
\text { Lung } \\
\text { Colon } \\
\text { Rectum } \\
\text { Prostate }\end{array}$ & $\begin{array}{l}\text { Total } \\
17844\end{array}$ & $\begin{array}{l}\text { Individual: } \\
\text { housing tenure; } \\
2 \text { categories }\end{array}$ & $1971-81$ & $\begin{array}{l}\text { Standardised } \\
\text { case fatality } \\
\text { ratio }\end{array}$ \\
\hline 14 & $\begin{array}{l}\text { South } \\
\text { Thames RHA } \\
\text { UK }\end{array}$ & Cervix & 1728 & $\begin{array}{l}\text { Individual: } \\
\text { social class based on } \\
\text { occupation; } 5 \text { categories }\end{array}$ & $1977-81$ & $\begin{array}{l}\text { Survival } \\
\text { rate* }\end{array}$ \\
\hline 15 & $\begin{array}{l}\text { West of Scotland, } \\
\text { UK }\end{array}$ & Cervix & 1588 & $\begin{array}{l}\text { Ecological: unweighed average of } \\
4 \text { census variables (eg semi- and } \\
\text { unskilled manual occupation) per } \\
\text { postcode of residence; } 7 \text { categories }\end{array}$ & $1980-87$ & $\begin{array}{l}\text { Corrected } \\
\text { survival rate }\end{array}$ \\
\hline 16 & Sweden & $\begin{array}{l}\text { Colon: men } \\
\text { women } \\
\text { Rectum: men } \\
\text { women } \\
\text { Prostate } \\
\text { Lung: men } \\
\text { women } \\
\text { Breast } \\
\text { Cervix }\end{array}$ & $\begin{array}{r}3828 \\
1946 \\
2659 \\
1048 \\
4752 \\
6587 \\
953 \\
11531 \\
4087\end{array}$ & $\begin{array}{l}\text { Individual: } \\
\text { occupation; } 2 \text { categories }\end{array}$ & $1961-79$ & $\begin{array}{l}\text { Relative } \\
\text { survival } \\
\text { rate }\end{array}$ \\
\hline 17 & Finland & Breast & 10181 & $\begin{array}{l}\text { Individual: social class based on } \\
\text { occupation; } 4 \text { categories }\end{array}$ & $1971-80$ & $\begin{array}{l}\text { Relative } \\
\text { survival rate, } \\
\text { Corrected } \\
\text { survival rate }\end{array}$ \\
\hline 18 & Finland & Colon & 2969 & $\begin{array}{l}\text { Individual: } \\
\text { social class based on } \\
\text { occupation; } 4 \text { categories }\end{array}$ & $1979-82$ & $\begin{array}{l}\text { Corrected } \\
\text { survival rate }\end{array}$ \\
\hline 19 & $\begin{array}{l}\text { Saarland, } \\
\text { Germany }\end{array}$ & $\begin{array}{l}\text { Colon } \\
\text { Rectum }\end{array}$ & $\begin{array}{l}1465 \\
1162\end{array}$ & $\begin{array}{l}\text { Ecological: score based on } \\
\text { occupation: \% of blue collar } \\
\text { workers aged } 15-65 \text { y per } \\
\text { community of residence; education: } \\
\% \text { with no more than } 9 \text { years } \\
\text { schooling per community of } \\
\text { residence; } 3 \text { categories }\end{array}$ & $1974-83$ & $\begin{array}{l}\text { Corrected } \\
\text { survival rate }\end{array}$ \\
\hline
\end{tabular}

* Whether a correction for other causes of death than the cancer was made is unknown

* No correction for other causes of death was made because the distributions of deaths related and not related to cancer were similar in the various socioeconomic status categories. 
lowest compared with the highest socioeconomic status category was taken directly from the paper. ${ }^{5-7111517-19}$ For two studies, ${ }^{812}$ we calculated an RR of dying with $95 \%$ confidence intervals $(95 \% \mathrm{CI}) .^{20}$ For one study, the ratios of standardised fatality rates were calculated; these are presented for men and women separately. ${ }^{13}$ For two studies we present a survival ratio, ${ }^{416}$ because an $R R$ of dying could not be calculated. A survival ratio is the ratio of the survival rate of the lowest to the highest socioeconomic status group and indicates worse survival for the lowest group if it is below 1.00.

For one study, only graphs were presented in the paper. ${ }^{16}$ We therefore obtained the original life tables from which five year relative survival rates had been abstracted and calculated $95 \%$ CIs from these. ${ }^{21}$

In some studies in which no survival differences were found no information was given on the exact RR or survival rates. ${ }^{114}$

For most studies we used the number of socioeconomic status categories originally distinguished by the authors. For one study, ${ }^{8}$ we reduced the original number of four categories to two, to provide a sufficient number of patients per category.

\section{Results}

Table 2 shows the results of the selected papers ordered by cancer site.

COLON CANCER

For colon cancer seven studies were included in the review. Two studies showed no association between socioeconomic status and survival. ${ }^{716}$ The other five studies all indicated a small survival advantage for colon cancer patients from the higher socioeconomic group. ${ }^{4111318}$ In one of these studies the survival difference was not statistically significant at the 5\% level, ${ }^{4}$ while in another only the raised RR for men was statistically significant. ${ }^{13}$ Finally, in one study there was no information on statistical significance. ${ }^{18}$

\section{RECTAL CANCER}

For cancer of the rectum, five studies are presented in table 2. Differences in survival were apparent in one study, ${ }^{19}$ in which the RR of dying in the lowest compared with the highest socioeconomic status group was statistically significantly $(<0.05)$ larger than $1 \cdot 00$. Three other studies also showed worse survival for the lowest socioeconomic status group, ${ }^{4716}$ although in two studies this was not a statistically significant difference, ${ }^{47}$ and in the third study this was only the case for men. ${ }^{16}$ Finally, one study showed (not statistically significant) opposite results for men $(R R=1 \cdot 18)$ and women $(\mathrm{RR}=0 \cdot 82) .^{13}$

\section{LUNG CANCER}

In the case of lung cancer, two studies presented a small, not statistically significant survival advantage for the highest socioeconomic status

Table 2 Results expressed as relative risk (RR) or survival ratio (SR) for the lowest relative to the highest socioeconomic status group

\begin{tabular}{|c|c|c|c|}
\hline $\begin{array}{l}\text { Study } \\
\text { ref }\end{array}$ & $\begin{array}{l}R R \text { of dying } \\
(95 \% \text { CI }) \text { or } p \text { value }\end{array}$ & $\begin{array}{l}S R \\
(95 \% C I) \text { or } p \text { value }\end{array}$ & Adjusted for \\
\hline $\begin{array}{l}\text { Colon: } \\
4 \\
7 \\
11 \\
13\end{array}$ & $\begin{array}{l}0.97(p>0.05) \\
1.26(1.04,1.52) \\
M: 1.44(p<0.05) \\
F: 1.11(p>0.05)\end{array}$ & $0.82(0.66,1.02)$ & $\begin{array}{l}\text { Age, sex, race, stage } \\
\text { Age, sex, race, stage } \\
\text { Age, place of residence } \\
\text { Age, period of follow up }\end{array}$ \\
\hline $\begin{array}{l}16 \\
18 \\
19 \\
\text { Rectum: }\end{array}$ & $\begin{array}{l}1 \cdot 15 \dagger \\
1.22(1.01,1.47)\end{array}$ & $M, F: 1.00(p>0.05)^{*}$ & $\begin{array}{l}\text { Age, sex, follow up year } \\
\text { Age, sex, stage, year of diagnosis, region, district }\end{array}$ \\
\hline $\begin{array}{r}4 \\
7 \\
13\end{array}$ & $\begin{array}{l}1.09(p>0.05) \\
M: 1.18(p>0.05) \\
F: 0.82(p>0.05)\end{array}$ & $0.79(0.60,1 \cdot 05)$ & $\begin{array}{l}\text { Age, sex, stage, race } \\
\text { Age, sex, stage, race } \\
\text { Age, period of follow up }\end{array}$ \\
\hline 16 & & $\begin{array}{l}\text { M: } 0.83(p<0.05) \\
\text { F: } 0.91(p>0.05)^{*}\end{array}$ & \\
\hline $\begin{array}{l}19 \\
\text { Lung: }\end{array}$ & $1 \cdot 32(1 \cdot 09-1 \cdot 60)$ & & Age, sex, stage, year of diagnosis, region, district \\
\hline $\begin{array}{l}11 \\
13\end{array}$ & $\begin{array}{l}\text { No difference } \\
\text { M: } 1.08(p>0.05) \\
\text { F: } 1.13(p>0.05)\end{array}$ & & $\begin{array}{l}\text { Age, histology, birth place } \\
\text { Age, period of follow up }\end{array}$ \\
\hline Prostate: & & $\begin{array}{l}\text { M: } 0.93(p>0.05) \\
\text { F: } 0.90(p>0.05)^{*}\end{array}$ & \\
\hline $\begin{array}{l}\text { Prostate: } \\
6 \\
13 \\
16 \\
\text { Breast: }\end{array}$ & $\begin{array}{l}1.86(p=0.03) \\
0.91(p>0.05)\end{array}$ & $0.94(p>0.05)^{*}$ & $\begin{array}{l}\text { Age, race } \\
\text { Age, period of follow up }\end{array}$ \\
\hline $\begin{array}{l}5 \\
8\end{array}$ & $\begin{array}{l}1.52(1 \cdot 28,1 \cdot 88) \\
\text { Boston: } 1.32(1.08,1.61) \\
\text { Tokyo: } 1.30(0.91,1.86)\end{array}$ & & $\begin{array}{l}\text { Age, race, tumour, stage, histology } \\
\text { Age }\end{array}$ \\
\hline $\begin{array}{l}11 \\
13 \\
16\end{array}$ & $\begin{array}{l}1.35(1.04,1.74) \\
0.98(p>0.05)\end{array}$ & $0.91(\mathrm{p}<0.05)^{*}$ & $\begin{array}{l}\text { Age, histology } \\
\text { Age, period of follow up }\end{array}$ \\
\hline $\begin{array}{l}17 \\
12 \\
\text { Cervix: }\end{array}$ & $\begin{array}{l}1.28(p<0.05) \\
1.1(0.99,1.23)\end{array}$ & 年 & Age, period of diagnosis, follow up year \\
\hline $\begin{array}{l}14 \\
15 \\
16\end{array}$ & $\begin{array}{l}\text { No difference }(p>0.05) \\
1.11(0.64,1.92)\end{array}$ & $0.91(\mathrm{p}<0.05)^{*}$ & $\begin{array}{l}\text { Age, tumour stage } \\
\text { Age, tumour stage, histology, tumour grade, } \\
\text { health board, year of treatment }\end{array}$ \\
\hline
\end{tabular}


group. ${ }^{1316}$ In one other study it was only mentioned that no survival difference was found. ${ }^{11}$

\section{PROSTATIC CANCER}

For cancer of the prostate one study found a rather high RR of dying for the lowest socioeconomic status category $(\mathrm{p}=0.03){ }^{6}$ The results of the two other studies showed either a slight, not statistically significant, survival advantage for the lowest socioeconomic status category ${ }^{13}$ or for the highest socioeconomic status category. ${ }^{16}$

\section{BREAST CANCER}

Data on socioeconomic differences in breast cancer survival come from six studies in this review. Except for one study, ${ }^{13}$ these all showed a raised $R R$ of dying for patients with the lowest socioeconomic status..$^{5111617}$ However, the results for Japan in one study were not statistically significant. ${ }^{8}$

\section{CERVICAL CANCER}

Finally, for cancer of the cervix only one study showed a statistically significant higher survival rate for the highest socioeconomic status group. ${ }^{16}$ Two studies showed a slight survival advantage for the highest socioeconomic status group, which was not statistically significant, ${ }^{12} 15$ while in the fourth study no difference in survival between socioeconomic groups was found. ${ }^{14}$

\section{Discussion}

We have reviewed results from 14 studies on socioeconomic differences in survival for six cancer sites. As can be seen from table 2, survival differences are generally rather small. Furthermore, results differ in relation to the cancer site. With regard to the results, we distinguished between three types of studies: (1) those showing a statistically significant difference in survival; (2) studies showing survival differences, which are not statistically significant; and (3) studies showing no survival difference according to socioeconomic status.

For cancers of the breast, colon, rectum, and cervix, most studies showed better survival for patients from higher socioeconomic groups. For these cancers all the statistically significant differences suggested a survival advantage for those of higher socioeconomic status, and most of the non-significant differences agreed with this.

The results are unclear both for lung cancer and cancer of the prostate. For lung cancer, only small, non-significant survival differences were found in two studies, ${ }^{1316}$ with the higher socioeconomic status groups showing an advantage, while no difference was found in the third study. ${ }^{11}$ For cancer of the prostate, the results of one study which showed significantly better survival for the higher socioeconomic status group, ${ }^{6}$ were contradicted by one ${ }^{13}$ of two studies that showed non-significant results.

In general, socioeconomic survival differ- ences are thought to be larger in cancers of relatively good prognosis, ${ }^{22}$ as earlier detection and treatment can be of greater influence on the survival for these cancers. This is more or less confirmed by our review, although the picture is less clear than expected.

For breast cancer, overall survival is rather good $^{23}$ and survival differences are relatively large. For lung cancer, which has the lowest overall survival probability of the six cancers studied, ${ }^{23}$ very small survival differences were found. The remaining four cancer sites have an intermediate level of survival. ${ }^{23}$ For cancers of the colon, rectum, and cervix survival differences according to socioeconomic status were found, which is in concordance with their overall level of survival. For cancer of the prostate, which has a better overall survival than colonic cancer, the results are less clear.

The general pattern of socioeconomic survival differences described above seems to be quite coherent. However, the results of the separate studies may have been influenced by their study design (for example, study population, measure of socioeconomic status, period of diagnosis) and data analysis (for example, number of other factors for which adjustment was made in the survival analysis, the reporting of confidence intervals). We will mention briefly some of the differences in study design and data analysis.

As we have already stated, study results might depend on the country of origin of the study population. We did not observe a systematic difference, however, in study results per country. Another important feature of study design concerns the measure of socioeconomic status which is used in a study. In general, ecological measures are more prone to misclassification than measures based on individual characteristics. This misclassification is probably not related to the outcome and therefore results in a bias towards the null hypothesis. For example, in one study the measure of socioeconomic status was based on the median male income per postcode of residence. ${ }^{11}$ This measure was also applied to female survival data, thereby causing even more probable misclassification.

Some individual measures of socioeconomic status, such as housing tenure, ${ }^{13}$ are only rough indicators. This could account for the inconsistency of the results from this study with those from other studies, for example, for breast cancer.

Overall, studies using an ecological measure $e^{4-711121519}$ did not differ substantially in their results from those using an individual measure. ${ }^{8131416-18}$

The measure of outcome employed in a study on socioeconomic status and cancer survival is another characteristic which may influence the study results. In studies using the relative survival rate as outcome, the expected survival rate is based on life tables of the general population. However, life expectancy of people from lower socioeconomic groups is lower than life expectancy of the general population. Therefore, their relative survival rate is underestimated, while for higher socioeconomic groups it is 
overestimated. Karjalainen and Pukkala ${ }^{17} \mathrm{com}$ pared socioeconomic differences in relative and corrected survival rates and showed that by using the relative rate the absolute difference in rates between the highest and lowest social class was larger. An overestimation of socioeconomic differences in cancer patient survival can thus result from using the relative survival rate, as in the Swedish study. ${ }^{16}$ For cancer of the cervix only, however, this study does ${ }^{16}$ show a larger difference in survival according to socioeconomic status than the other studies. ${ }^{121415}$

Although it was not clear whether correction for deaths from causes other than cancer was made in four studies, ${ }^{581214}$ results of these studies did not differ substantially from those of other studies.

The number and type of variables for which adjustment in the survival analysis was made also varied across studies, which made a comparison of results rather difficult. For cervical cancer, however, the results from three UK studies are consistent, although in the analysis of one study adjustment was made for many variables, ${ }^{15}$ while in two other studies this was not the case. ${ }^{1214}$

It is important to know, as we noted in the introduction, whether socioeconomic differences in cancer mortality are mainly caused by incidence or survival differentials. We therefore compared our findings on survival with published data on cancer mortality according to socioeconomic status for the six cancer sites which were studied. The selected studies concern patients diagnosed between the second half of the 1960 s and the beginning of the $1980 \mathrm{~s}$ in Finland, ${ }^{1}$ Australia, ${ }^{2425}$ New Zealand, ${ }^{26}$ Switzerland, ${ }^{27}$ the UK, ${ }^{28-30}$ and the USA. ${ }^{31}$

For rectal cancer no association exists between socioeconomic status and mortality. ${ }^{25} 2630$ Mortality is higher in lower socioeconomic groups for cancers of the lung ${ }^{124-30}$ and cervix. ${ }^{1252729}$ For cancers of the colon, prostate, and breast, either no mortality differences were found (colon, ${ }^{25}{ }^{30}$ prostate, ${ }^{26}{ }^{29}{ }^{31}$ breast $^{2729}$ ) or there was higher mortality in higher socioeconomic status groups (colon ${ }^{2426}$, prostate $^{252730}$, breast ${ }^{125}$ ).

If we compare our findings on cancer survival with the published data on socioeconomic differences in cancer mortality, we come to the following conclusions.

For lung cancer, the higher mortality in the lower socioeconomic groups cannot be ascribed to socioeconomic differences in survival, which seemed to be rather small and insignificant. Mortality differences must therefore be the result of differences in incidence. This is confirmed by findings from studies on socioeconomic status and lung cancer incidence, which showed a higher incidence for the socially disadvantaged. ${ }^{25293233}$

For cancer of the cervix, higher mortality was found for the lower socioeconomic groups, while small survival differences were found in the reviewed papers for this cancer. These mortality differences must therefore be the result of the socioeconomic differences in cancer incidence which have been reported in several studies and which indicate a higher incidence in the lower socioeconomic status groups. ${ }^{25} 293334$

For cancers of the breast and colon, mortality was higher in higher socioeconomic status groups in some, but not all, studies, while survival seemed to be better in these groups. Thus, for these cancers, the better survival for patients from higher socioeconomic status groups could somewhat weaken the positive association between socioeconomic status and mortality, or make it totally disappear in some situations. The incidence for these cancers is higher in the higher socioeconomic status groups (breast, ${ }^{25} 333435$ colon $^{253335}$ ) which confirms that mortality differences for these cancers are also mainly caused by differences in incidence.

For rectal cancer, no socioeconomic gradient in mortality was found, but survival differences do exist. With regard to incidence too, no socioeconomic gradient was found, ${ }^{2533}$ which makes the evidence on the impact of incidence and survival differences according to socioeconomic status on mortality differences rather inconclusive.

Finally for cancer of the prostate mortality was higher in higher socioeconomic status groups in some studies, while results on survival were inconsistent. The mortality differences according to socioeconomic status for this cancer seem to be caused by socioeconomic differences in incidence. This is confirmed by the finding in several studies that the incidence of this cancer is higher in men from high socioeconomic groups. ${ }^{25} 333536$

We conclude that overall the impact of socioeconomic differences in cancer survival on differences in cancer mortality is low. Socioeconomic differences in cancer mortality are mainly caused by differences in incidence. Health policy measures in the field of primary prevention aimed at known cancer risk factors should therefore be taken to reduce socioeconomic differences in cancer mortality.

The authors thank D Vagerö who kindly supplied the original life tables from his published study.

1 Valkonen T, Martelin T, Rimpelä A. Socio-economic mortality differences in Finland 1971-1985. Helsinki: Central Statistical Office of Finland, 1990.

2 Fox AJ, Goldblatt PO. Longitudinal Study, socio-demographic mortality differentials 1971-1975. London: Office of Population Censuses and Surveys, 1982. Series LS no 1.

3 Freedman LS. Tables of the number of patients required in clinical trials using the logrank test. Stat Med 1982;1: 121-9.

4 Wegner EL, Kolonel LN, Nomura AMY, Lee J. Racial and socioeconomic status differences in survival of colorectal cancer patients in Hawaii. Cancer 1982;49:2208-16.

5 Bassett MT, Krieger N. Social class and black-white differences in breast cancer survival. Am $\mathcal{F}$ Public Health 1986; 76:1400-3.

6 Dayal HH, Polissar L, Dahlberg S. Race, socioeconomic status, and other prognostic factors for survival from prostate cancer. F Natl Cancer Inst 1985;74:1001-6.

7 Dayal H, Polissar L, Yang CY, Dahlberg S. Race, socioeconomic status, and other prognostic factors for survival from colo-rectal cancer. $\mathcal{F}$ Chron Dis 1987;40:857-64.

8 Morrison AS, Lowe CR, MacMahon B, Ravnihar B, Yuasa $S$. Incidence risk factors and survival in breast cancer: report on five years of follow-up observation. Eur $\mathcal{F}$ Cancer 1977;13:209-14.

9 Salber EJ, Trichopoulos D, MacMahon B. Lactation and reproductive histories of breast cancer patients in Boston, 1965-1966. ₹ Nat Cancer Inst 1969;43:1013-24. 
10 Yuasa S, MacMahon B. Lactation and reproductive histories of breast cancer patients in Tokyo, Japan. Bull World Health Organ 1970;42:195-204.

11 Bonett A, Roder D, Esterman A. Determinants of case survival for cancers of the lung, colon, breast and cervix survival for cancers of the lung, colon, breast and

12 Milner PC, Watts M. Effect of socioeconomic status on survival from cervical cancer in Sheffield. $\mathcal{F}$ Epidemiol Community Healch

13 Kogevinas M, Marmot MG, Fox AJ, Goldblatt PO. Socioeconomic differences in cancer survival. $\mathcal{F}$ Epidemiol Community Health 1991;45:216-9.

14 Murphy M, Goldblatt P, Thornton-Jones H, Silcocks P. Survival among women with cancer of the uterine cervix: influence of marital status and social class. $\mathcal{f}$ Epidemiol Community Health 1990;44:293-6.

15 Lamont DW, Symonds RP, Brodie MM, Nwabineli NJ, Gillis CR. Age, socio-economic status, and survival from cancer of cervix in the West of Scotland 1980-1987. Br $\Im$ Cancer 1993;67:351-7.

16 Văgerö $D$, Persson $G$. Cancer survival and social class in Sweden. 7 Epidemiol Community Health 1987;41:204-9.

17 Karialainen S, Pukkala E. Social class as a prognostic factor in breast cancer survival. Cancer 1990;66:819-26.

18 Auvinen A. Social class and colon cancer survival in Finland. Cancer 1992;70:402-9.

19 Brenner H, Mielck A, Klein R, Ziegler H. The role of socioeconomic factors in the survival of patients with colorectal cancer in Saarland/Germany. $f$ Clin Epidemiol 1991;44:807-15.

20 Vandenbroucke JP, Hofman A, van Stiphout WAHJ. Grondslagen der epidemiologie. Utrecht: Bunge, 1991;157-8.

21 Parkin DM, Hakulinen T. Analysis of survival. In: Jensen OM, Parkin DM, MacLennan R, Muir CS, Skeet RG, eds. Cancer registration: principles and methods. Lyon: IARC, eds. Cancer registration: princi

22 Berg JW, Ross R, Latourette HB. Economic status and survival of cancer patients. Cancer 1977;39:467-77.

23 Hanai A, Fujimoto I. Survival rate as an index in evaluating cancer control. In: Parkin DM, Wagner G, Muir CS, eds. The role of the registry in cancer control. Lyon: IARC, 1985. IARC sci publ 66 .
24 McMichael AJ. Social class (as estimated by occupational prestige) and mortality in Australian males in the 1970s. Community Health Studies 1985;9:220-30.

25 Williams J, Clifford C, Hopper J, Giles G. Socioeconomic status and cancer mortality and incidence in Melbourne. Eur J Cancer 1991;27:917-21.

26 Pearce NE, Howard JK. Occupation, social class and male cancer mortality in New Zealand, 1974-1978. Int f Epidemiol 1986:15:456-62.

27 Levi F, Negri E, La Vecchia C, Te VC. Socioeconomic groups and cancer risk at death in the Swiss canton of Vaud. Int $\mathcal{F}$ Epidemiol 1988;17:711-7.

28 Balarajan R, McDowall ME. Regional socioeconomic differences in mortality among men in Great Britain today. Public Health 1988;102:33-43.

29 Kogevinas E. Longitudinal Study. Socio-demographic differences in cancer survival. London: HMSO 1990. Series LS no 5.

30 Davey-Smith G, Leon D, Shipley MJ, Rose G. Socioeconomic differentials in cancer among men. Int $\mathcal{F}$ Epidemiol 1991;20:339-45.

31 Ernster VL, Selvin S, Sacks ST, Austin DF, Brown SM, Winkelstein W. Prostatic cancer: mortality and incidence rates by race and social class. Am f Epidemiol 1978;107: rates by

32 Devesa SS, Diamond EL. Socioeconomic and racial differences in lung cancer incidence. Am $\mathcal{F}$ Epidemiol 1983;118: 818-31.

33 Vågerö D, Persson G. Occurrence of cancer in socioeconomic groups in Sweden. Scan f Soc Med 1986;14: 151-60.

34 Devesa SS, Diamond EL. Association of breast cancer and cervical cancer incidences with income and education among whites and blacks. $\mathcal{F}$ Natl Cancer Inst 1980;65: 515-28.

35 Rimpelä AH, Pukkala EI. Cancers of affluence: positive social class gradient and rising incidence trend in some cancer forms. Soc Sci Med 1987;24:601-6.

36 Ross RK, McCurtis JW, Henderson BE, Menck HR, Mack TM, Martin SP. Descriptive epidemiology of testicular and prostatic cancer in Los Angeles. Br $\mathcal{F}$ Cancer 1979; 39:284-92. 
20 National Research Council. Recommended dietary allowances. 10th ed. Washington, DC: National Academy Press, 1989.

21 McLaughlin PJ, Weihrauch JL. Vitamin E content of foods. f Am Diet Assoc 1979;75:647-65.

22 Järvinen R, Seppänen R, Knekt P. Short-term and longterm reproducibility of dietary history interview data. In term reproducibility of diet

23 Brockington F. World health. Appendix VIII. The in ternational standard classification of occupations, 2nd edn London: Churchill, 1967:331-9.

24 Cohen J, Cohen P. Applied multiple regression/correlation analysis for the behavioral sciences. New York: John Wiley \& Sons, 1975.

25 Pao EM, Mickle SJ, Burk MC. One-day and 3-day nutrien intakes by individuals - Nationwide Food Consumption Survey findings, spring 1977. F Am Diet Assoc 1985;85: 313-24.

26 Murphy SP, Subar AF, Block G. Vitamin E intakes and sources in the United States. Am F Clin Nutr 1990;52. 361-7.

27 Bolton-Smith C, Woodward M, Brown CA, TunstallPedoe $H$. Nutrient intake by duration of ex-smoking in the Scottish heart health study. BrF Nutr 1993;69:315-32.

28 Knekt P, Seppänen R, Aaran R-K. Determinants of serum alpha-tocopherol in Finnish adults. Prev Med 1988;17: alpha-tocop.

29 Järvinen R, Knekt P, Seppänen R, Heinonen M, Aaran R-K Dietary determinants of serum $\beta$-carotene and serum retinol. Eur f Clin Nutr 1993;47:31-41.

30 Bolton-Smith C, Smith WCS, Woodward M, TunstallPedoe $\mathrm{H}$. Age trends in nutrient intakes for non-manual and manual occupational groups: the Scottish heart health study (abstract). Proc Nutr Soc 1990;49:63A.

31 Seppänen R. Nutrition in Finland. (In Finnish.) Duodecim 1982;98:1666-73.

32 Aro S, Räsänen L, Telama R. Social class and changes in health-related habits in Finland in 1973-1983. Scand 7 Soc Med 1986;14:39-47.

33 Braddon FEM, Wadsworth MEJ, Davies JMC, Cripps HA. Social and regional differences in food and alcohol consumption and their measurement in a national birth consumption and their measurement in a national birth

34 Hulshof KFAM, Löwik MRH, Kok FJ, et al. Diet and other life-style factors in high and low socio-economic groups (Dutch nutrition surveillance system). Eur $\mathcal{f}$ Clin Nutr 1991;45:441-50.

35 Preston AM. Cigarette smoking - nutritional implications Prog Food Nutr Sci 1991;15:183-217.

36 Stryker WS, Kaplan LA, Stein EA, Stampfer MJ, Sober A, Willett WC. The relationship of diet, cigarette smoking, and alcohol consumption to plasma beta-carotene and alpha-tocopherol levels. Am $\mathcal{F}$ Epidemiol 1988;127:283-96.

37 Schectman G. Estimating ascorbic acid requirements for cigarette smokers. Ann NY Acad Sci 1993;686:335-45.

38 Subar AF, Harlan LC, Mattson ME. Food and nutrient intake differences between smokers and non-smokers in the US. Am F Public Health 1990;80:1323-9.

39 Cade JE, Margetts BM. Relationship between diet and smoking - Is the diet of smokers different? $f$ Epidemiol Cokming the diet of smokers d

40 Herbeth B, Chavance M, Musse N, Vernhes G. Determinants of plasma retinol, beta-carotene, and alphaterminants of plasma retinol, beta-carotene,

41 Knekt P. Vitamin E and smoking and the risk of lung cancer. Ann NY Acad Sci 1993;686:280-7.

42 Kato I, Tominaga S, Suzuki T. Characteristics of past smokers. Int $\mathcal{F}$ Epidemiol 1989;18:345-54.

43 Baecke JAH, van Staveren WA, Burema J. Food con sumption, habitual physical activity, and body fatness in young Dutch adults. Am f Clin Nutr 1983;37:278-86.

44 Prentice AM, Black AE, Coward WA, et al. High levels of energy expenditure in obese women. BMf 1986;292 $983-7$.

\section{Cancer patient survival by socioeconomic status in seven countries: a review for six common cancer sites}

Carola T M Schrijvers, Johan P Mackenbach

\begin{abstract}
Study objective - To study the size and consistency of socioeconomic differences in cancer patient survival as reported in published studies.

Methods - A systematic review was coriducted. Several criteria were developed to select the study material, which resulted in 14 reports on socioeconomic differences in survival for cancers of the colon, rectum, lung, prostate, breast, and cervix. These present results on patients from the United States, Japan, Australia, United Kingdom, Sweden, Finland, and Germany. The results are summarised in a relative risk of dying or survival ratio for
\end{abstract}

the lowest socioeconomic status group compared with the highest.

Results - For cancers of the colon, rectum, breast, and cervix, patients from higher socioeconomic status groups had a better survival. For lung cancer and cancer of the prostate, results were unclear.

Conclusion-Socioeconomic differences in cancer survival are generally small and their contribution to socioeconomic differences in cancer mortality is probably small too. These findings have implications for the type of health policy measures which should be taken to reduce socioeconomic differences in cancer mortality.

Corrigendum: An article was published in the October issue entitled "Cancer patient survival by socioeconomic status in The Netherlands: a review for six common cancer sites" ( $F$ Epidemiol Community Health 1994; 48: 441-6). This title was incorrect and misleading. The corrected title is printed above, together with the abstract. 